\title{
Peran Orang Tua Terhadap Pengetahuan Seks Pada Anak Usia Dini
}

\author{
Andi Nur Andriani Achmad \\ Sulfasyah \\ Universitas Muhammadiyah Makassar \\ sulfasyah@unismuh.ac.id \\ Muhammad Nawir \\ Universitas Muhammadiyah Makassar \\ muhammadnawir@unismuh.ac.id
}

\begin{abstract}
ABSTRAK
Setiap orang tua harus berperan penting dalam mendidik anak tentang pendidikan seks kepada anak namun masih ada beberapa orang tua yang menganggap tabuh. Tujuan penelitian ini untuk mengetahui peran orang tua terhadap pengetahuan seks pada anak usia dini, Jenis penelitian yang dilakukan adalah penelitian kualitatif. Informan ditentukan secara purposive sampling, berdasarkan karakteristik informan yang telah ditetapkan yaitu orang tua yang mempunyai anak Usia Dini. Teknik pengumpulan data yaitu observasi, dokumentasi dan wawancara mendalam. Teknik analisis data melalui berbagai tahapan yaitu reduksi data, penyajian data dan penarikan kesimpulan, sedangkan teknik keabsahan data menggunakan triangulasi sumber, waktu dan teknik. Hasil penelitian menunjukan bahwa pentingnya peran orang tua dalam mendidik anak tentang pendidikan seks anak usia dini agar anak dapat mengetahui fungsi-fungsi alat refroduksinya dan anak dapat menjaga diri jika berada diluar rumah dan anak dapat mewaspadai orang-orang yang berada disekitarnya baik itu orang yang tidak dikenalinya maupun orang yang dikenalinya. Adapun kendala orang tua dalam melakukan sosialisasi pendidikan seks kepada anak yaitu karena terlalu tingginya bahasa yang orang tua sampaikan kepada anak sehingga anak tidak dapat memahami apa yang dikatakan oleh orang tua, dan juga karena kurangnya perhatian anak kepada orang tua dalam menerima pengajaran pendidikan seks anak ini.
\end{abstract}

Kata Kunci : Peran Orang Tua, Pendidikan Seks, Anak Usia Dini.

\section{PENDAHULUAN}

Hubungan terkecil dari suatu masyarakat yang memiliki suatu keterkaitan satu sama lain, biasa disebut keluarga. Keluarga terdiri dari ayah, ibu dan anak. Pengertian dari keluarga sendiri meupakan kesatuan dari orang-orang yang berinteraksi dan berkomunikasi yang menciptakan peran-peranan sosial bagi sang suami dan istri, putra dan putri, saudara laki-laki dan saudara perempuan peran sosial dalam setiap keluarga berbeda-beda, salah satunya peran orang tua dalam memberikan pendidikan karena pada dasarnya Pendidikan adalah hal mutlak yang wajib dimiliki oleh semua individu, di dalam setiap ajaran agama menganjurkan agar setiap individu wajib berusaha untuk mendapatkan pendidikan. Pendidikan dapat diperoleh melalui jalur formal, non formal dan informal. 
Pendidikan formal lebih difokuskan pada pemberian keahlian atau skill guna terjun ke masyarakat Dalam lingkungan formal ini setiap individu akan mendapatkan pendidikan yang lebih luas mengenai pedoman dan etika moral kemanusiaan untuk bekalnya dalam menghadapi pergaulan di masyarakat. Lingkungan ketiga yang menjadi penentu sukses tidaknya pendidikan individu adalah lingkungan masyarakat (Nonformal), lingkungan ini menuntut pengaplikasian pendidikan yang telah didapat oleh seorang individu baik dari lingkungan keluarga maupun dari lingkungan formal.

Pendidikan non formal merupakan mekanisme yang memberikan peluang bagi setiap orang untuk memperkaya ilmu pengetahuan dan teknologi melalui pembelajaran seumur hidup. Pendidikan nonformal adalah setiap kesempatan dimana terdapat komunikasi yang teratur dan terarah di luar sekolah. Dalam pergaulannya di masyarakat, individu harus mempunyai etika dan sopan santun.

Pendidikan dalam lingkungan keluarga (In-formal) memiliki peranan yang sangat penting. Ini karena setiap individu mendapatkan pendidikan yang pertama berasal dari lingkungan keluarga.Di dalam keluarga individu dididik untuk menjadi seorang anak yang baik, yang tahu sopan santun dan etika serta mempunyai moral sifat yang terpuji. Selain dari keluarga pendidikan dapat diperoleh pula dari lingkungan formal, dalam hal ini sekolah atau lembaga formal lainnya yang berkompeten dalam bidang pendidikan. Pendidikan formal yang sering disebut pendidikan persekolahan, berupa rangkaian jenjang pendidikan yang telah baku misalnya PAUD, SD, SMP, SMA dan PT (Perguruan Tinggi). Dan manusia harus mulai dididik sejak usia dini, karena pada Masa usia dini sering dikatakan sebagai masa keemasan atau golden age. Masa keemasan adalah masa dimana anak memiliki kemampuan penyerapan informasi yang sangat pesat, dibandingkan tahap usia selanjutnya. Kepesatan kemampuan otak anak dalam menyerap berbagai informasi di sekitarnya juga diiringi dengan rasa ingin tahu yang sangat tinggi. Rasa ingin tahu yang sangat tinggi ditunjukkan anak dengan aktif bertanya tentang berbagai hal yang mereka temui, serta mencari tahu berbagai jawaban yang mereka inginkan dengan bereksplorasi.

Rasa ingin tahu anak meliputi beragam bidang termasuk hal yang berkaitan dengan seksualitas. Menurut Andriana (2006: 81) perkembangan gender dan seksualitas pada anak-anak dimulai dari hal yang paling mendasar, antara lain pada usia tiga tahun anak sudah dapat membedakan jenis kelamin dan perbedaan fisik yang menyertainya. Seksualitas berkembang sejak masa anak-anak, remaja, sampai dewasa. Perkembangan 
ini meliputi perkembangan fisik dan psikis, perkembangan secara psikis berupa perkembangan psikoseksual yang terjadi pada masa anak-anak (Nurani, 2013: 59).

Sigmund Freud dalam (Nurani, 2013: 59) membagi perkembangan psikoseksual pada masa anak-anak menjadi empat fase, yaitu fase oral,fase anal, fase falik, dan fase laten. Pada fase oral berlangsung sejak bayi lahirhingga usia 1-2 tahun. Pada fase ini, mulut merupakan pusat kenikmatan bagi bayi, oleh karena itu bayi senang mengisap jari ke dalam mulutnya. Adapun fase anak berlangsung mulai usia sekitar 2-4 tahun. Pada fase ini, daerah dubur dan sekitarnya merupakan pusatkenikmatan. Sedangkan fase falus/falik, mulai dari usia 4-6 tahun, pada tahap ini anak merasakan alat kelaminnya sebagi bagian yang menyenangkan. Oleh karena itu, pada pada fase ini anak senang bereksplorasi dengan alat genitalnya. Dan yang terakhir yaitu fase laten, yang berlangsung pada usia sekolah Pada bagaian awal fase ini, anak tidak lagi memusatkan perhatian pada alat genitalnya.

Sebagaimana penelitian yang dilakukan oleh Kusumawati (2009: 85) pada salah satu TK di Mojokerto membuktikan bahwa terdapat hubungan yang bermakna antara tingkat pengetahuan orang tua tentang pendidikan seks dini dengan perilaku seks pada anak usia 3 sampai 6 tahun. Oleh karena itu peran orang tua sebagai pemberi informasi awal mengenai seks pada anak menjadi salah satu faktor yang akan mempengaruhi perkembangan dan kehidupan anak pada masa yang akan datang.

\section{LANDASAN TEORI}

Keluarga merupakan unit sosial terkecil yang terdiri dari ayah, ibu dan anak. Lingkungan yang berhubungan dengan anak adalah orang tuanya, saudara-saudaranya yang lebih tua (jika ada), serta mungkin kerabat dekatnya yang tinggal serumah. Melalui lingkungan tersebut si anak akan mengenal dunia sekitarnya dan pola pergaulan hidup yang berlaku sehari-hari. Keluarga juga memiliki fungsi majemuk bagi terciptanya kehidupan sosial dalam masyarakat. Dalam keluarga, diatur hubungan antara anggotaanggotanya sehingga setiap anggota keluarga mempunyai peran dan fungsinya yang jelas. peranan adalah perilaku yang diharapkan oleh pihak lain dalam melaksanakan hak dan kewajiban sesuai dengan status yang dimilikinya. Status dan peranan tidak dapat dipisahkan karena tidak ada peranan tanpa statuss dam tidak ada status tanpa peranan. Menurut Nurhayati (2007), tanggung jawab orang tua tidak hanya mencakup atau terbatasi pada kebutuhan materi saja, tetapi sesungguhnya mencakup juga kepada seluruh aspek kehidupan anaknya, termasuk di dalamnya aspek pendidikan seksual. Di dalam 
suatu keluarga, peran orang tua sangatlah penting bagi seorang anak. Hal tersebut dikarenakan dengan peran yang dimiliki oleh orang tua tersebut maka akan dapat mempengaruhi perilaku anak. Ketika seorang anak ingin berperilaku maka anak tersebut akan menyesuaikan perilakunya dengan perilaku orang-orang di sekitarnya. Apabila orang tua dapat menjalankan peran dengan baik dengan memberikan contoh perilakuperilaku yang baik dan benar maka akan mempengaruhi anak untuk bertindak atau berperilaku yang sama dengan kedua orang tuanya (Nurdin, dkk 2015).

Pendidikan Seks (sexeducation) adalah suatu pengetahuan yang kita ajarkan mengenai segala sesuatu yang berhubungan dengan jenis kelamin. Ini mencakup mulai dari pertumbuhan jenis kelamin (Laki-laki atau wanita). Bagaimana fungsi kelamin sebagai alat reproduksi. Bagaimana perkembangan alat kelamin itu pada wanita dan pada laki-laki. Tentang menstruasi,mimpi, basah dan sebagainya, sampai kepada timbulnya birahi karena adanya perubahan pada hormon-hormon. Termasuk nantinya masalah perkawinan, kehamilan dan sebagainya.

Sehingga pendidikan seks sudah seharusnya diberikan kepada anak-anak agar anak-anak dapat membedakan mana yang boleh diperlihatkan kepada orang dan mana yang tidak, baik melalui pendidikan formal maupun informal. Ini penting untuk mencegah kekerasan seksual bagi anak usia dini, sex education maupun pengetahuan tentang kesehatan reproduksi dikalangan masyarakat .Kita ketahui bahwa manusia itu diciptakan berjenis-jenis, yaitu laki-laki dan perempuan. Kalau kamu ditanya apa seks kamu,tentu kamu menjawab laki-laki dan perempuan. Sedangkan ciri-ciri, sifat atau peranan dari masing- masing jenis kelamin itulah yang disebut dengan seksualitas. Seksualitas juga bias diartikan sebagai dorongan atau kehidupan seks itu sendiri, yakni segala sesuatu alia stotalitas dari kehidupan seseorang laki- laki dan perempuan meliputi penampilan fisik, emosi, psikologi, juga intelektual mereka. Seks dan Seksualitas itu sesuatu yang alami terjadi pada manusia karena itu adalah sesuatu hal yang sangat normal.

Rasa ingin tahu (curiosit), tidak hanya milik para ilmuan dan peneliti. Namun, rasa ingin tahu yang besar sebenarnya ada pada diri anak-anak. Dalam kehidupan seharihari, kita menyaksikan betapa anak-anak memiliki rasa ingin tahu yang besar. Mereka akan menanyakan sesuatu mengapa begitu, mengapa begini, bagaimana hal itu terjadi, dan apa sebabnya. Sebagai orang dewasa, kita sering terhenyak dan kelabakan Maka kita harus waspada terhadap jawaban yang keliru karena apa yang kita jelaskan pada anak akan terusdi ingat anak sampai dewasa. Karena itu, kita harus menjawab pertanyaan anak dengan benar dan dapat dipertanggung jawabkan. Informasi tentang seks diberikan 
sedikit demi sedikit, hari demi hari, agar pertanyaan anak dapat dijawab secara jujur dan jelas. Menurut Dr. Wilson W. Grant, Dalam bukunya "From Parent to Child About Sex" menyatakan bahwa cara menerapkan pendidikan seks pada anak-anak ialah dengan penjelasan sedikit demi sedikit, dari hari kehari. "Menurut para ahli (pakar) ilmu jiwa, perkembangan masa anak-anak adalah masa meniru dan mencontoh. Karena apa yang dilihatdan didengar oleh anak-anak akan ditirunya". (Afra,2011)

Pengertian Anak usia dini secara umum adalah anak-anak yang berusia di bawah 6 tahun. Jadi mulai dari anak itu lahir hingga ia mencapai umur 6 tahun ia akan dikategorikan sebagai anak usia dini. Beberapa orang menyebut fase atau masa ini sebagai "golden age" karena masa ini sangat menentukan seperti apa mereka kelak jika dewasa baik dari segi fisik, mental maupun kecerdasan. Pengertian anak usia dini adalah anak yang berada pada rentang usia 0-6 tahun (Undang-Undang Sisdiknas tahun 2003 dalam Alwahdania 2013:37) dan sejumlah ahli pendidikan anak memberikan batasan 0-8 tahun. Anak usia dini didefinisikan pula sebagai kelompok anak yang berada dalam proses pertumbuhan dan perkembangan yang bersifat unik. Mereka memiliki pola pertumbuhan dan perkembangan yang khusus sesuai dengan tingkat pertumbuhan dan perkembangannya (Mansur, 2005 dalam Alwahdania, 2013:43) Pada masa tersebut merupakan masa emas (golden age), karena anak mengalami pertumbuhan dan perkembangan yang cukup pesat dan tidak tergantikan pada masa mendatang. Menurut banyak penelitian bidang neurologi ditemukan bahwa 50\% kecerdasan anak terbentuk pada kurun waktu 4 tahun pertama. Setelah usia 8 tahun, perkembangan otaknya mencapai 80\% dan pada usia 18 tahun mencapai 100\% (Suyanto, 2005 dalam Alwahdania, 2013:43). Mengacu pada Undang-undang Sisdiknas tahun 2003 pasal 1 ayat 14, upaya pembinaan yang ditujukan bagi anak usia 0-6 tahun tersebut dilakukan melalui Pendidikan Anak Usia Dini (PAUD). Pendidikan anak usia dini dapat dilaksanakan melalui pendidikan formal, nonformal dan informal. Pendidikan anak usia dini jalur formal berbentuk taman kanak-kanak (TK) dan Raudatul Athfal (RA) dan bentuk lain yang sederajat. Pendidikan anak usia dini jalur nonformal berbentuk kelompok bermain (KB), taman penitipan anak (TPA), sedangkan PAUD pada jalur pendidikan informal berbentuk pendidikan keluarga atau pendidikan yang diselenggarakan lingkungan seperti bina keluarga balita dan posyandu yang terintegrasi PAUD atau yang kita kenal dengan Satuan PAUD Sejenis (SPS). Berbagai pendidikan untuk anak usia dini jalur non formal terbagi atas tiga kelompok yaitu kelompok Taman Penitipan Anak (TPA) usia 0-6 tahun); Kelompok Bermain (KB) usia 2-6 tahun; kelompok SPS usia 0-6 tahun. 
Dari uraian pengertian anak usia dini menurut para ahli di atas, dapat disimpulkan bahwa anak usia dini adalah anak yang berada pada rentang usia 0-6 tahun yang sedang mengalami pertumbuhan dan perkembangan yang sangat pesat, sehingga diperlukan stimulasi yang tepat agar dapat tumbuh dan berkembang dengan maksimal. Pemberian stimulasi tersebut melalui lingkungan keluarga, PAUD jalur non formal seperti tempat penitipan anak (TPA) atau kelompok bermain (KB) dan PAUD jalur formal seperti TK dan RA. Karakteristik Anak Usia Dini.

Teori interaksi atau perkembangan ditemukan oleh piaget. Piaget percaya bahwa anak-anak itu membangun pengetahuan melalui interaksi dengan lingkungan. Anak-anak bukan merupakan objek penerima pengetahuan yang pasif, melainkan mereka dengan aktif melakukan pengaturan penglaman mereka kedalam struktur mental yang kompleks. Selanjutnya Piaget menguraikan tentang pemikiran anak-anak mengenai konsep asimilasi, akomodasi dan keseimbangan. Asimilasi terjadi ketika anak melakukan pencocokan informasi kekategori yang sudah ada. Jika kemudian diberikan pengetahuan tentang kucing maka anak akan menciptakan suatu kategori baru dimana bukan hanya anjing hewan berbulu yang dapat digendong ditimang. Mnciptakan suatu kategori baru adalah bagian dari akomodasi anak yang mana secepatnya menciptakan suatu struktur mental yang berkaitan dengan semua hewan yang ada.

Jhon Ames Comenius sangat percaya bahwa pendidikan harus dimulai sejak dini karena Seorang anak akan berkembang secara menyeluruh. Perkembangan disuatu area pasti memengaruhi perkembangann direa lain, contoh ketika anak menjadi gesitnya membuka lebih banyak lagi hal-hal lain dari berbagai kemungkinan untuk melakukan eksplorasi dan belajar tentang lingkungan. Anak-anak yang merasaakan bahwa mereka sedang belajar dengan sukses atau anak-anak yang merasa yakin tentang kemampuan fisik mereka memiliki kepercayaan diri yang baik. Anak-anak yang belajar untuk mampu mengendalikan perilaku mereka yang impulsive dapat berinteraksi dengan orang lain atau alat-alat permainan dalam waktu yang lebih lama, dimana hal inijugaberpengaruh terhadap perkembangan intelektual mereka. Perkembangan social, fisik dan intelektual selalu berkitan

\section{METODE PENELITIAN}

Penelitian ini adalah penelitian sosial budaya dengan Jenis penelitian yang dilakukan adalah penelitian kualitatif yang bertujuan mengetahui tentang peran orang tua terhadap pendidikan seks pada anak usia dini di kota makassar. Informan ditentukan secara, purposif sampling atau 
judgmental sampling yaitu teknik penarikan informan dengan tujuan tertentu. Teknik yang digunakan untuk memperoleh data yang dibutuhkan dalam penelitian ini adalah metode observasi langsung, wawancara, dokumentasi, dan studi pustaka. Dan menggunakan teknik keabsahan data trianggulasi sumber, teknik, dan waktu.

\section{PEMBAHASAN}

Setelah menyajikan hasil penelitian, pada bagian ini peneliti akan membahasnya agar lebih jelas lagi dan dapat lebih dimengerti. Bertolak dari rumusan masalah dalam penelitian yang telah dilakukan kepada pengkajian judul Peran Orang Tua Terhadap Pendidikan Seks Pada Anak Usia Dini Di Desa Cambaya Kecamatan Ujung Tanah Kota Makassar melalui kegiatan observasi, wawancara dan dokumentasi terhadap informan yang telah ditetapkan sebelumnya sebagai informan peneliti yang merupakan sumber informan utama. Dapat disajikan hasil penelitian pada setiap rumusan masalah yakni,

1. Peran Orang Tua Terhadap Pengetahuan Seks Pada Anak Usia Dini Di Desa Cambaya Kecamatan Ujung Tanah:

a. Peran Orang Tua Dalam Keluarga

Orang tua berperan penting dalam mendidik, menjaga dan mengawasi anak dan orang tua yang baik harus menjaga komunikasi yang baik kepada anak mereka apalagi yang masih berusia dini, dan orang tua harus menyisihkan waktunya untuk anak dalam mendegar cerita ataupun permasalahan yang anak rasakan, baik itu permasalahan yang ada diluar rumah, sekolah, lingkungan, maupun dalam rumah sendiri

b. Peran Orang Tua Dalam Memberikan Pendidikan Seks Bagi Anak Usia Dini

Orang tua memang harus mengajarkan atau memberitahukan tentang perbedaan jenis kelamin antara perempuan dan laki-laki. Adapun perbedaan yang secara eksternal maupun internal pada remaja cowok maupun cewek, Kekerasan seksual pada anak sexual abuse merupakan salah satu bentuk kekerasan yang dapat mengakibatkan trauma yang cukup berat baik secara fisik mau psikis dan dapat bertahan dalam waktu yang cukup lama. Beberapa perilaku seksual anak yang dianggap tidak wajar kerap dijumpai dalam tayangan berita diberbagai media informasi, kolom konsultasi psikologi, Jadi pendidikan seks ini sangat penting diterapkan kepada anak, karena Pendididkan seks bertujuan untuk mengenalkan anak tentang jenis kelamin dan cara menjaganya baik dari sisi kesehatan dan kebersihan, keamanan, serta keselamatan. Sementara pengetahuan reproduksi sangat berkaitan dengan proses perkembangbiakan makhluk hidup. Reproduksi memungkinkan kelangsungan hidup suatu spesies. Manusia, hewan, dan tumbuhan dapat berkembang 
biak karena peran reproduksi. Pendidikan seks pendidikan mengenai kesehatan reproduksipenting diberikan lewat keluarga maupun kurikulum sekolah. Sedini mungkin anak harus bisa menjaga dirinya sendiri.

2. Kendala Orang Tua Dalam Melakukan Sosialisasi Pendidikan Seks Bagi Anak Usia Dini Di Desa Cambaya Kecamatan Ujung Tanah

\section{a. Pendidikan Seks Anak Usia Dini Perlu Di Terapkan}

pendidikan seks ini perluh sekali diterapkan kepada anal-anak agar anak dapat menjaga diri terhadap orang-orang asing maupun yang dikenalinya, anak-anak harus waspada agar anak terhindar dari tindakan kekerasan seksual atau pencabulan pada anak usia dini, Untuk mencegah terjadinya kekerasan seksual terhadap anak perlunya peran orang dewasa atau orang terdekat anak, dalam hal ini yaitu orang tua agar dapat memberikan informasi mengenai pendidikan seks terhadap anak. Maka dalam hal ini diperlukan bekal orang tua untuk menjadi lebih terbuka serta informatif terhadap anak khususnya mengenai pendidikan seksual agar dapat memberikan pendampingan yang baik bagi anak dan diharapkan anak terhindar dari perilaku penyimpangan seksual dan orang tua di haruskan mengajarkan anak tentang pendidikan seks sedini mungkin.

b. Kendala Dalam Memberikan Penjelasan Mengenai Pendidikan Seks Bagi Anak Usia Dini

Orang tua berhak mengajarkan anak tentang pendidikan seks anak usia dini ini mulai dari keluarganya sendiri, dari orang tuanya dulu tentang pengenalan-pengelan alat refroduksinya dalam menjaga dan melindungi bagian-bagian tertentu yang telah dilarang untuk memperlihatkannya kepada orang asing maupun kepada orang yang dikenal guna untuk menjaga dan melindungi agar anak dapat mandiri dan dapat mnejaga dirinya sendiri ketika dia berada diluar rumah, karena pada dasarnya tidak ada pendidikan yang dapat membuat anak-anak menjadi takut untuk bersosialisasi begitu pula dengan pendidikan seks anak usia dini yang mampu menanamkan nilai-nilai moral kepada anak dan dapat membuat anak menjadi dapat bertanggung jawab dengan dirinya sendiri maupun kepada orang tua dan juga kepada orang yang berada disekitarnya

\section{KESIMPULAN}

Berdasarkan hasil penelitian yang telah disajikan dalam pembahasan pada terdahulu, maka dapat ditarik kesimpulan sebagai berikut :

1. Peran orang tua terhadap pengetahuan seks pada anak usia dini sangat-sangat penting bagi pertumbuhan dan pengetahuan anak, karena selain dapat mengajarkan 
tentang kesehatan dan menjaga diri pendidikan seks ini juga dapat membantu anak mewaspadai orang-orang disekelilingnya agar anak dapat terhindar dari perbuatan kekerasan seksual pada anak, walaupun tidak semua orang tua yang masih beranggapan bahwa pendidikan seks anak pada anak masih dianggap tabuh oleh sebgaian kalangan, tapi karena telah maraknya perilaku orang yang tidak bertanggung jawab yang melakukan kekerasan seksual pada anak maka orang tua terdorong untuk mnegajarkan pendidikan seks ini kepada anak merekam agar anak dapat melindungi dirinya sendiri.

2. Kendala orang tua dalam melakukan sosialisasi pendidikan seks anak usia dini yaitu karena orang tua memakai bahasa yang kurang bisa anak pahami dan terlalu berbelit-belit ketika menjelaskan kepada anak, dan anakpun kurang merespon apa yang dikatakan orang tua karena anak-anak biasa lebih suka mendengar ataupun gampang memahami jika orang tua cerita ketika ada contoh ataupun dalam bentuk gambar

\section{DAFTAR PUSTAKA}

Andriana. (2006). Hubungan Komunikasi Dalam Keluarga Dengan Perilaku Seksual Beresiko Pada Remaja Di Smk Nusatama Padang. Skripsi Tidak Diterbitkan. Bandung: FMIPA UPI

Alwahdania. (2013). Pendidikan Seks Dalam Keluarga Bagi Anak Usia Remaja. Skripsi. Makassar: UNHAS

Afra, Afifah. Dan Supriyanto Ahmad. (2011). Pendidikan Seks Untuk Remaja. Surakarta: Gizone Publishing.

Bungin, Burhan. (2006). Sosiologi Komunikasi. Jakarta: Kencana Prenada Media Group.

Bogdan, Robert dan Steven J. Taylor. (1992). Pengantar Metode Penelitian Kualitatif. Surabaya: Usaha Nasional

Diana, Septi. (2016). Pentingnya Pendidikan Seks (Seks Education). "Digtat”: UNM

Gasa, Abdal. (2015). Pola Relasi Beragama Komunitas Towani Tolotang Di Masyarakat Amparita Kabupaten Sidrap. Skripsi tidak diterbitkan. Makassar: Unismuh Makassar.

Herjanti. (2014). Pola Asuh Orang Tua Tentang Pendidikan Seks Anak Usia Dini. Skripsi. Jakarta: STIK Indonesia Maju

Irianto, K. (2010). Memahami Seksologi. Bandung. Sinar Baru Algensindo 
Kartono, Kartini. (1985). Peranan Keluarga Memandu Anak. Jakarta : CV. Rajawali

Kustiasari Tika. (2011). Peran Pendidikan Anak Usia Dini (Paud) Terhadap Sosialisasi Anak Di Dalam Keluarga. Skripsi. Jakarta: UI

Kusumawati. (2009). Peran Kerjasama Guru Dan Orang Tua Dalam Memberikan Pendidikan Seks Bagi Anak. Skripsi. Jakarta: UNJ

Maghfirah. (2006). Al-Qur'an Tajwid dan Terjemahannya. Mataram: Mitra

Muhammadiyah, Marham. (2014). Sosiologi Keluarga. "Diktat". Makassar: Universitas Muhammadiyah Makassar.

Nurani, Yuliani. (2013). Konsep Dasar Anak Usia Dini, Jakarta: Pt Indeks.

Nurdin, N. \& Hambali, H. (2015). Partisipasi Tokoh Masyarakat Dalam Memberikan Pendidikan Seks pada Anak. equilibrium, 3(2), 195-202.

Prastowo, Andi. (2001). Metode Penelitiankualitatif Dalam Perspektif Rancangan Penelitian. Jogjakarta: Ar-RuzzMedia

Soekanto, Soerjono. (1982). Sosiologi Suatu Pengantar. Jakarta : PT Raja Grafindo Persada

Sulistiani Niken. (2012). Peran Orang Tua Dalam Mencegah Perilaku Seks Bebas Pada Anak. Skripsi. Ponorogo: Unismuh Ponorogo

Tim Penyusun. (2015). Buku Pedoman Penulisan Skripsi. Makassar: Unismuh Makassar

Widyati Lestari. (2015). Peran Orang Tua Dalam Pendidikan Seks Pada Remaja. Skripsi Tidak Diterbitkan. Surakarta: UMSUS

Yuniati Nurrina. (2008). Pendidikan Seks Yang Islami Bagi Anak-Anak (Kajian Atas Pemikian Abdullah Ulwan). Skripsi Tidak Diterbitkan. Makassar: UIN

Zuraiq. (2004). Penanggulangan Budaya Seks Bebas Pada Remaja. Skripsi. Makassar: UIN

Nurhayati Syarifuddin, "Pentingnya Pendidikan Seks Bagi Keluarga, Remaja Dan Anak". Http//Pentingnya PendidikanSeks BagiKeluarga, Remaja Dan Anak« Stan Prodip Pajak Angkatan1998. Htm 